\title{
Acids can promote the onset and multimorbidity of allergic and nonallergic airway diseases
}

\author{
Giuliano Molinari ${ }^{1,2}$, Laura Molinari ${ }^{2,3}$, Elsa Nervo $^{4}$ \\ ${ }^{1}$ Federazione Nazionale degli Ordini dei Chimici e dei Fisici, 00185 Rome, Italy \\ ${ }^{2}$ Studio Tecnico Ing. Laura Molinari, Environmental Health and Safety, 37138 Verona, Italy \\ ${ }^{3}$ Consiglio Nazionale degli Ingegneri, 00187, Rome, Italy \\ ${ }^{4}$ Società Chimica Italiana, 00198 Rome, Italy \\ Giuliano Molinari, corresponding author \\ E-Mail: giuliano.molinari@,fastwebnet.it \\ Orcid ID: https://orcid.org/0000-0002-9278-5727
}

Short Title: Acids promote allergic diseases

\begin{abstract}
Inflammatory allergic and nonallergic respiratory pathologies often co-exist. The root cause is not clear. This paper demonstrates that it is ascribable to protons $\left(\mathrm{H}^{+}\right)$released into cells by exogenous and endogenous acids.

The hypothesis of acids as the common cause stems from two considerations:

a) it has long been known that exogenous acids present in air pollutants can induce the irritation of epithelial surfaces, particularly the airways, inflammation and bronchospasm;

b) according to recent articles, endogenous acids, generated in cells by phospholipases, play a key role in the biochemical mechanisms of initiation and progression of allergic responses. Therefore, the intracellular acidification and consequent $\mathrm{Ca}^{2+}$ increase, induced by protons generated by either acid pollutants or endogenous phospholipases, may be the causal mechanism of the multimorbidity of these diseases, and environmental acidity may contribute to their spread.
\end{abstract}

Keywords: Acid, Air pollution, Allergic diseases, $\mathrm{Ca}^{2+}$, Mechanisms of allergy, Multimorbidity, Nonallergic, Nonatopic. 


\section{Introduction}

\section{Allergies and the environment}

Inflammation and hypersensitivity of the airways and epidermis, whether allergic/atopic or nonallergic/nonatopic, acute or chronic, are pandemic illnesses. Epidemiological studies show that they are growing faster in developing countries ${ }^{1}$. The increase has been attributed to several factors, both genetic ${ }^{2}$ and environmental ${ }^{3}$. This work focuses on the latter.

Environmental factors that can affect the aetiology of these diseases, such as lifestyle, climate change, and air contaminants, have long been the subject of study and debate the world over ${ }^{3-7}$. The World Health Organization (WHO) has provided recommendations on how to reduce air pollution in closed environments, produced by household activities, one of these being to properly ventilate the home ${ }^{7}$. This is very useful in rural areas but not in cities or industrial areas, where the outside air is often more polluted than the air indoors. Consequently, today inflammatory allergic and nonallergic pathologies are more widespread in urban than rural areas ${ }^{8}$. Authoritative research confirms that the higher prevalence in urban areas correlates with some outdoor air pollutants ${ }^{3,8-12}$. Immunological effects can be observed in both the human nose and the lower airways after exposure to diesel exhaust. The short-term exposure to traffic-related nitrogen dioxide $\left(\mathrm{NO}_{2}\right)$, an acidic gas, has a direct effect on respiratory morbidity ${ }^{11}$. Furthermore, a relationship between allergic diseases, Black Carbon (BC) and Particulate Matter $\left(\mathrm{PM}_{2.5}\right)^{13}$ and between air pollutants and allergic infant sensitization has been demonstrated ${ }^{13}$. The MeDALL European project confirmed the relevance of environmental exposures ${ }^{14,15}$. Recent research has provided some therapeutic improvements ${ }^{16}$. However, further studies are needed to discover the molecular determinants and onset mechanisms of allergic and nonallergic diseases ${ }^{12,16}$.

\section{Studies of the basic mechanisms of allergic and nonallergic reactions}

In addition to the relevance of environmental exposures, the MeDALL study highlighted that air pollution not only correlates with bronchitis, rhinitis, asthma, and even eczema ${ }^{8-13}$, but these diseases often co-exist and share causal mechanisms ${ }^{14,15,17}$.

While the mechanism of allergic response has been extensively studied and remains mainly an $\mathrm{IgE} /$ FceRI-based, individual hypersensitivity reaction to specific allergens ${ }^{1,4}$, there is no fully convincing biochemical explanation of the nonallergic response and the relationship between increasing allergic and nonallergic hypersensitivities, their multimorbidity, and air pollutants. IgE sensitization can no longer be considered the dominant causal mechanism of multimorbidity of such diseases ${ }^{14,15,17}$, because allergic symptoms exist even in the absence of positive IgE tests. For these non-IgE-associated diseases it is necessary to hypothesize other mechanisms, which should be investigated ${ }^{4,15,17}$. Some studies proved that this is in part attributable to genetic predisposition. Regarding the consequences of environmental pollution, many studies have analysed toxic effects induced by air pollutants, in particular oxidative ${ }^{18}$ and nitrosative ${ }^{3,9}$ stress, and the causal relationship with allergies. Studies of acid stress began in the $80 \mathrm{~s}^{19,20}$, without investigating the correlation between extra- and intracellular acidity. The aim of this work is to highlight the chemism of atmospheric acid pollutants, their irritating effects on the airways and the existence of a possibly shared causal biochemical mechanism, induced by both exogenous and endogenous acids, for the onset and spread of allergic and nonallergic inflammatory diseases.

Scientific literature available on-line from 1970 to December 2018 was taken into consideration. We analysed the data and critically evaluated the fundamental concepts concerning the topic under study. 


\section{Relevant results of experimental research}

\section{Outdoor acid air pollutants: chemical and toxicological characteristics}

Polluting atmospheric acids damage surface waters, buildings and living organisms either by direct reaction or through acid rain. Epidemiological studies on acute respiratory effects have shown that fine particulate matter $\left(\mathrm{PM}_{2.5}\right)$ and gaseous acid pollutants can have a major impact on the airways ${ }^{6}$, $9,21,22$, because of their significant toxic potential. Given their small size, they are able to penetrate in depth and reach the lower respiratory airways ${ }^{11,23}$. Furthermore, due to their low polarity and high liposolubility, the gases can spread quickly through biological membranes ${ }^{11,24}$ and hence enter cells. Among these gases, $\mathrm{NO}$ and $\mathrm{O}_{3}$ are known to cause nitrosative and oxidative stress,

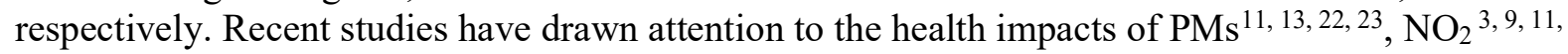
$13,21,25$, and $\mathrm{SO}_{2}{ }^{26-28}$.

It is known that PMs are acidic. In addition, $\mathrm{NO}_{2}$ and $\mathrm{SO}_{2}$ can react with water and oxygen to give the corresponding acids, nitric acid $\left(\mathrm{HNO}_{3}\right)$, sulphurous acid $\left(\mathrm{H}_{2} \mathrm{SO}_{3}\right)$, sulphuric acid $\left(\mathrm{H}_{2} \mathrm{SO}_{4}\right)$ and their related acidic salts. The toxicity of acid compounds is mainly due to their ability to release protons $\left(\mathrm{H}^{+}\right)$. Both $\mathrm{HNO}_{3}$ and $\mathrm{H}_{2} \mathrm{SO}_{4}$ are strong acids, important sources of protons, and therefore are fiercely corrosive. While, at normal temperature and pressure, $\mathrm{NO}_{2}$ and $\mathrm{SO}_{2}$ are gases, the corresponding acids $\mathrm{HNO}_{3}, \mathrm{H}_{2} \mathrm{SO}_{3}$, and $\mathrm{H}_{2} \mathrm{SO}_{4}$ are liquids, easily soluble in water. Their acidic salts are water-soluble as well. Therefore, most air acidity is concentrated in the microscopic PMs, suspended in the air itself, in the form of both moist solid particles and watery droplets, known as acid aerosols. Notably, for its smaller particle size and its larger specific surface area, $\mathrm{PM}_{2.5}$ is richer than $\mathrm{PM}_{10}$ in water and acids.

Around the year 1985, interest in the effects of acid aerosols increased, due to the risk of high exposure levels in US and Canada. Clinical studies were carried out to assess the toxicity of some atmospheric pollutants. The results showed that:

- The bronchoconstrictor action of carbachol could be enhanced by acid sulphate aerosols ${ }^{19,29}$, even though the sulphate is not itself toxic ${ }^{29}$.

- The biologically active portion of these compounds is $\mathrm{H}^{+}$rather than sulphate and the potency is proportional to their acidity ${ }^{29}$.

- Titratable acidity appears to be a more important stimulus to bronchoconstriction than $\mathrm{pH}^{30}$.

Consistently, it was shown that bronchoconstriction provoked by inhalation of sodium sulphite aerosols was caused by the released gaseous $\mathrm{SO}_{2}$, or by bisulphite, but not by sulphite ${ }^{30}$. Combined exposures to acidic aerosols and pollutant gases have synergic effects.

The above-mentioned $\mathrm{PMs}, \mathrm{HNO}_{3}, \mathrm{H}_{2} \mathrm{SO}_{3}$, and $\mathrm{H}_{2} \mathrm{SO}_{4}$ are the strongest acid components of acid aerosols. In addition, some other weaker acids are present, including carbonic acid, nitrous acid, and hydrogen sulphide, which essentially contribute to titratable acidity. All acids can contribute to the effects of total air acidity by releasing $\mathrm{H}^{+} \mathrm{s}$ to different extents. Current environmental legislation sets limits for several air pollutants in each country. However, no limit exists for the total acidity of air, even though it has been reported that $\mathrm{H}^{+}$can play a very important and diversified role in respiratory epithelial tissues, at both intracellular and extracellular level.

\section{Physio-pathological effects of cellular acidification in epithelial tissues}

It has been shown that exogenous acids can cause irritation and the bronchoconstriction of the airways $^{19,20,29-31}$ in both asthmatic ${ }^{20}$ and healthy subjects ${ }^{31}$. Moreover, they can stimulate both immune cells (mast cells ${ }^{32}$, neutrophils ${ }^{33-35}$, dendritic cells $\mathrm{s}^{36}$, eosinophils ${ }^{37}$, Jurkat cells and primary $\mathrm{T}$ cells ${ }^{38-40}$ ) and non-immune cells (epithelial cells ${ }^{41,42}$, fibroblasts ${ }^{20}$, and smooth airway muscle cells $^{43-45}$. It is possible that the effects of limited exposure by healthy subjects are negligible, because air acidity can be entirely neutralized within a short time by the buffering capacity of 
airway surface liquid (ASL) ${ }^{46}$. On the contrary, major exposure or, for sensitive people even limited exposure, can overcome the ASL defence, giving rise to the transfer of $\mathrm{H}^{+}$into the cell as described below.

Regarding endogenous acids, it should be remembered that cells use intracellular enzymes such as phospholipase $\mathrm{C}$ (PLC) and messengers such as inositol 1,4,5-trisphosphate $\left(\mathrm{IP}_{3}\right)$ to increase the free $\mathrm{Ca}^{2+}$ concentration in cytosol $\left(\left[\mathrm{Ca}^{2+}\right]_{\mathrm{c}}\right)$. PLC and other phospholipases are powerful acidifying enzymes, because one $\mathrm{H}^{+}$is released for each hydrolysed ester bond ${ }^{47-49}$. The hydrolysis of phospholipid esters and the generation of endogenous acids, such as arachidonic acid (AA), phosphatidic acid, and $\mathrm{IP}_{3}$, are at the base of the production of allergic mediators. It is known that acidification can cause mobilization of the segregated $\mathrm{Ca}^{2+}$ from intracellular stores ${ }^{33,34,41,42,50-54}$, because protons can readily replace $\mathrm{Ca}^{2+}$ in its ligand locations ${ }^{48,55,56}$. Moreover, it is known that the increase of $\left[\mathrm{Ca}^{2+}\right]_{\mathrm{c}}$ is involved in many physiological processes ${ }^{57-61}$ but also in the triggering of pathological manifestations such as allergic responses ${ }^{59}$, airway hyper-responsiveness (AHR) ${ }^{60}$, and abnormal contraction and remodelling of airway smooth muscle (ASM) ${ }^{61}$.

The two paragraphs below give a more detailed description of the biochemical mechanisms by which intra- and extracellular acidification take place and foster allergic reactions.

Intracellular $\mathrm{H}^{+}$: intracellular acidification may be caused by the action of phospholipases in the cytosol or by protons entering the cell through the plasma membrane.

The cells responsible for triggering the allergic response, such as mast cells ${ }^{4,59,62-64}$ and basophils ${ }^{4}$, 63-65, have numerous receptors sensitive to various agonists. These receptors can be classified historically as IgE-dependent and non-IgE-dependent receptors, based on their positive or negative response to immunoglobulins $\mathrm{E}(\mathrm{IgE})^{66}$. The best example of an IgE-dependent receptor is the High affinity $\operatorname{IgE}$ receptor (FceRI) ${ }^{67,68}$. Non-IgE-dependent receptors include the recently discovered GProtein-Coupled Receptors (GPCR) which respond to less specific agonists ${ }^{63,65,69-72}$. Also in the GPCR group are Mas-related G-protein coupled receptors (MRGR ${ }^{66,70}$, protease-activated receptors $(\mathrm{PAR})^{73}$ and purinergic receptors ${ }^{74}$. Given the sheer number of GPCRs, many combinations with different agonists are possible. For example, GPR4, GPR65, GPR68 and GPR132 receptors may be activated by extracellular protons ${ }^{43,44,48,75,76}$. Alternatively, muscarinic agonists may stimulate the Gaq/11 subunits of the acetylcholine GPCRs ${ }^{43}$. So-called pseudoallergic agents also follow this route ${ }^{77}$. All individuals can respond via GPCR receptors to the stimulus of the agonist, but only sensitized individuals (the "truly" allergic) can respond via $\mathrm{IgE} / \mathrm{Fc} c \mathrm{RI}$.

Contact between the agonist and the receptor triggers complex chain reactions which, via the activation of numerous enzymes and the increase in the concentration of $\mathrm{H}^{+}$and cytosolic $\mathrm{Ca}^{2+}$ (respectively $\left[\mathrm{H}^{+}\right]_{\mathrm{c}}$ and $\left[\mathrm{Ca}^{2+}\right]_{\mathrm{c}}$ ), culminates with degranulation, by the exocytotic secretion of allergic mediators and the onset of an acute allergic response. The responses of the various agonist/receptor couples may differ ${ }^{63,71,78}$, but depend in each case on the concentration and affinity of the agonist ${ }^{68}$ and the fundamental steps in the basic biochemical mechanism of allergic reactions do not vary (Fig. 1):

- The stimulation of the receptor, both of the FceRI and GPCR types, activates phospholipase $\mathrm{C}$ (PLC) ${ }^{79-82}$ and hence the hydrolysis of phosphatidylinositol 4,5-biphosphate (PIP2) on the inner wall of the plasma membrane, generating and releasing IP3 in the cytosol.

- Through dissociation the IP3 releases $\mathrm{H}^{+83}$ and, via its IP3R receptor, induces cell calcium release and store depletion, increasing $\left[\mathrm{Ca}^{2+}\right]_{\mathrm{c}}{ }^{84}$.

- The increase in $\left[\mathrm{Ca}^{2+}\right]_{\mathrm{c}}$ activates numerous calcium-dependent enzymes, including phospholipase $\mathrm{A}_{2}\left(\mathrm{PLA}_{2}\right)$, which produces arachidonic acid (AA $)^{85,86}$, which in turn dissociates releasing further $\mathrm{H}^{+}$and inducing the release of further $\mathrm{Ca}^{2+51,53,87}$; from the AA 
hundreds of derivatives (eicosanoids cascade) are formed, including leukotrienes (LTs) and prostaglandins (PGs) ${ }^{88,89}$.

- The store depletion stimulates the entry of further $\mathrm{Ca}^{2+}$ from the extracellular space (calcium influx) via the mechanism known as SOCE (Store Operated Calcium Entry), in which, from the surface of the Endoplasmic Reticulum (ER), STIM1 (Stromal Interaction Molecule1) activates the opening of ORAI1 and Transient Receptor Potential Cation Canonical (TRPC) $)^{90-93}$ channels on the plasma membrane.

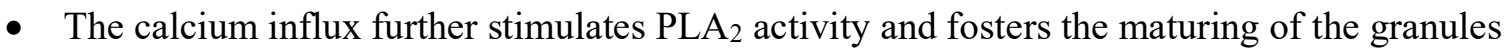
and subsequent degranulation and release ${ }^{94-97}$ of mediators ${ }^{88,98,99}$, including histamine, PGs, LTs, cytokine, tryptase and chymase, which promote the acute phase of allergic inflammation. The cysteinyl LTs are thought to be responsible for the increase in the basal tone of the ASM and in bronchoconstriction in asthma ${ }^{4,100 .}$

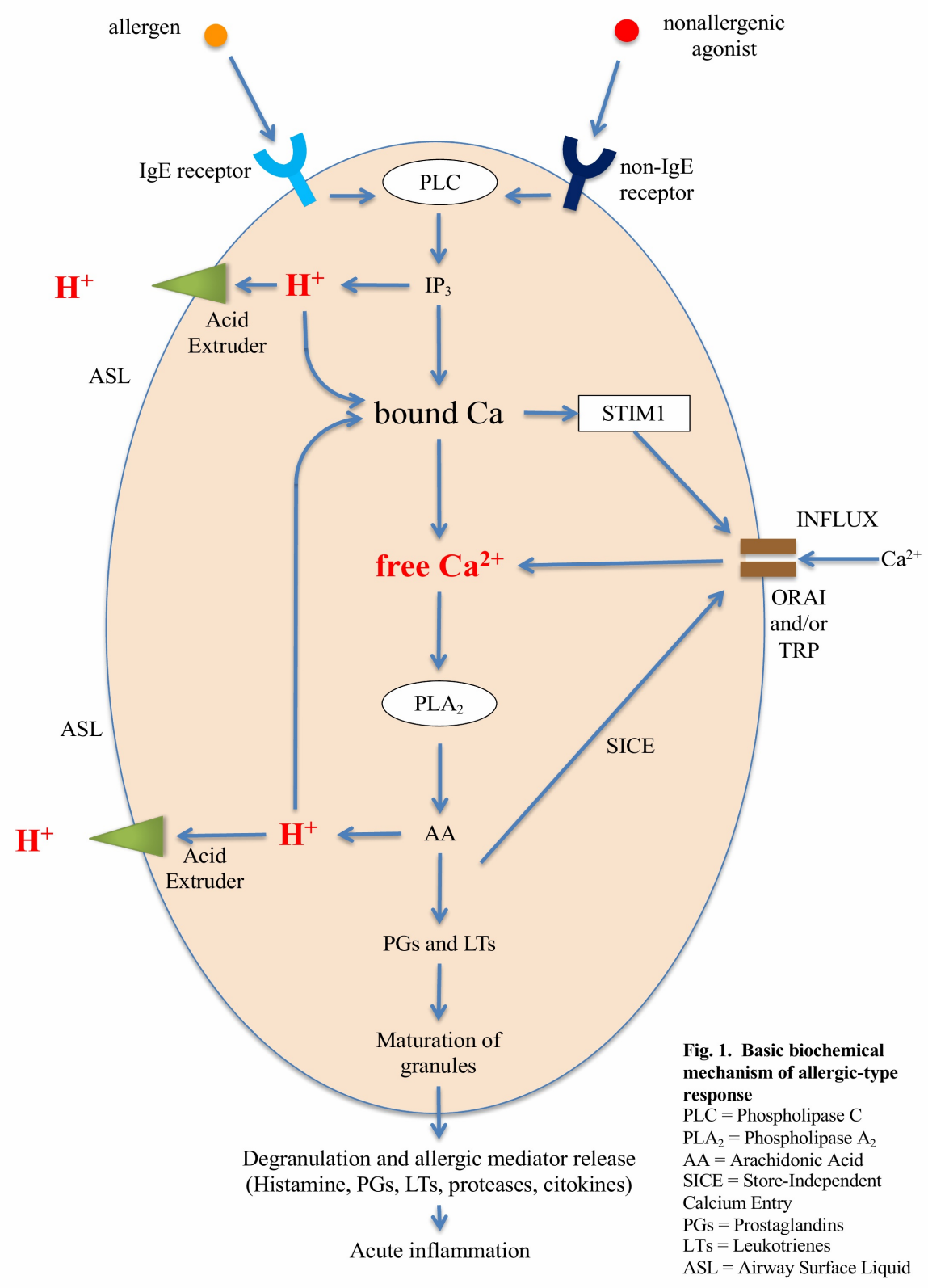


Fig. 1 shows two different steps in the intracellular generation of $\mathrm{H}^{+}$through the action of phospholipase, the first dependent on the IP 3 produced by PLC, the second on the AA produced by $\mathrm{PLA}_{2}$. Both give rise to a rapid transient increase in $\left[\mathrm{H}^{+}\right]_{\mathrm{c}}$. This increase, due to the protons derived from the dissociation of the $\mathrm{IP}_{3}$ and the $\mathrm{AA}$, contributes to cell store depletion/calcium release and the increase in $\left[\mathrm{Ca}^{2+}\right]_{\mathrm{c}}{ }^{34,42,51-54,83,101}$. The rise in $\left[\mathrm{H}^{+}\right]_{\mathrm{c}}$ is subject to feedback control and can be rapidly neutralized by the buffering capacity of cytosol and the calcium influx, which leads to the alkalization of the cytosol, because the extracellular $\mathrm{pH}$ outweighs the intracellular $\mathrm{pH}$. The influx may also be induced by a mechanism other than SOCE and independently of the reserves, known as Store-Independent Calcium Entry (SICE), by direct activation, via STIM1 and ORAI, due to the AA or Lts ${ }^{102}$.

In addition to being generated in the cytosol by the phospholipases as described above, $\mathrm{H}^{+}$can penetrate the cell directly, passing through the epithelial barrier and plasma membrane, thanks to the acid loaders (Fig. 2, A). The permeability of the epithelial barrier can vary as a result of the stimuli received from the cellular receptors ${ }^{103}$ or the barrier itself may be destroyed ${ }^{104,105}$. At least four different mechanisms are known for the entry of protons through the plasma membrane via acid loaders ${ }^{24,106-117}$ :

1. the transfer of $\mathrm{H}^{+}$from the extracellular space to intracellular space may take place through the ubiquitous Transient Receptor Potential (TRP) channels. Although their main function is the extrusion of protons from the cells [106], some types of TRP are sensitive to acids and enable the entry of ions such as $\mathrm{H}^{+}$and $\mathrm{Ca}^{2+107-112}$. In addition to the TRPs, the cell can use other channels ${ }^{113}$, such as ORAIs ${ }^{112}$ or Acid-Sensing Ion Channels (ASICs) ${ }^{48,76,114}$;

2. $\mathrm{H}^{+}$can be released into the cell after entry by passive transfer of reactive oxides, such as $\mathrm{CO}_{2}, \mathrm{NO}_{2}$ and $\mathrm{SO}_{2} . \mathrm{CO}_{2}$ can react with water to release $\mathrm{H}^{+}$much quicker than $\mathrm{NO}_{2}$ and $\mathrm{SO}_{2}$ due to the specific ubiquitous catalyst Carbonic Anhydrase (CA $)^{106}$. Therefore, the $\mathrm{CO}_{2} / \mathrm{CA}$ system is possibly an excellent means of transport for $\mathrm{H}^{+}$, as some researchers believe ${ }^{33,106}$; on the other hand, the real permeability of the membrane to $\mathrm{CO}_{2}$ and other gases is still under discussion ${ }^{24,115}$;

3. to lower intracellular $\mathrm{pH}$, the cell may use $\mathrm{Cl}^{-} / \mathrm{HCO}_{3}{ }^{-}$exchangers of the SLC26 type, such as SLC26A4, SLC26A6 and SLC26A9116, 117, which are commonly present on the apical membrane of epithelia in the airways and can be activated by the lowering of extracellular $\mathrm{pH}^{118}$;

4. finally, it should be remembered that excess protons have a unique ability to migrate into aqueous systems by Grotthuss shuttling ${ }^{106,119,120 .}$

Extracellular $\mathrm{H}^{+}$: the acidification of the surfaces of the respiratory airways may be due to endogenous acids or environmental acid pollutants

The outer surface of the epithelia of respiratory pathways is kept moist at all times by ASL. ASL plays a key role in the defence of the airways from pathogens and contains some phagocytes and a number of proteic and peptidic antimicrobials for this purpose. For optimum antimicrobial activity, both in the nose and lungs, ASL pH should be maintained within slightly acidic physiological values (circa $\mathrm{pH}=6,80)^{20,121,122}$ and a lowering can be counterproductive ${ }^{123}$. Interestingly, a decrease of ASL $\mathrm{pH}$ after exposure to airborne traffic pollutants has been detected in asthmatic ${ }^{123}$ and healthy subjects ${ }^{124}$, albeit to different extents.

Historically, endogenous acidification of the airway surfaces has been suggested as a way to measure airway disease ${ }^{121}$. In 2000, Hunt et al. demonstrated that the $\mathrm{pH}$ of Exhaled Breath Condensate (EBC) was over two log orders lower in patients with acute asthma than in healthy subjects. Hence, they suggested a possible causal relationship between endogenous airway acidification and the airflow limitation observed in acute asthma ${ }^{125}$. Similarly, in more recent years, low $\mathrm{pH}$ values of ASL have been observed by other authors in asthma, allergic rhinitis, atopic 
dermatitis $^{126}$, and even in non-allergic inflammatory diseases, such as bronchiectasis and Chronic Obstructive Pulmonary Disease (COPD) ${ }^{105}$.

Fig. 2, B shows the possible causes of the lowering of ASL pH depending on endogenous or exogenous acidity. Extracellular and ASL acidification may be caused by:

5. $\mathrm{H}^{+}$derived from the physiological process of restoring pre-stimulus conditions, carried out by all cells through the expulsion of excess protons, generated by phospholipase, to return to the steady state;

6. the degranulation of mast cells and basophils, caused by the stimulus, the basis of the acute allergic response, as described above in Fig. 1 127;

7. the degranulation of phagocytes, such as macrophages and granulocyte neutrophils and eosinophils ${ }^{124}$, produced as a defensive inflammatory action ${ }^{20,121}$ in response to the stimulus. This action may be significant and long-lasting and is therefore the basis for chronic disease. It is known that, like phagocytes, basophils and mast cells ${ }^{127}$ can produce and secrete acids and phospholipolytic enzymes with the contents of their cytosolic granules and vesicles. Examples of secreted acids are lactic, hypochlorous, uric, phosphoric acid, and fatty acids. Examples of enzymes are the cytosolic and secretory phospholipases $\mathrm{A}_{2}$, which produce fatty acids such as AA through hydrolysis of cellular triglycerides and phospholipids ${ }^{128}$. Each of the secreted acids can contribute to the release of protons and thus act as new stimuli for physio-pathological responses.

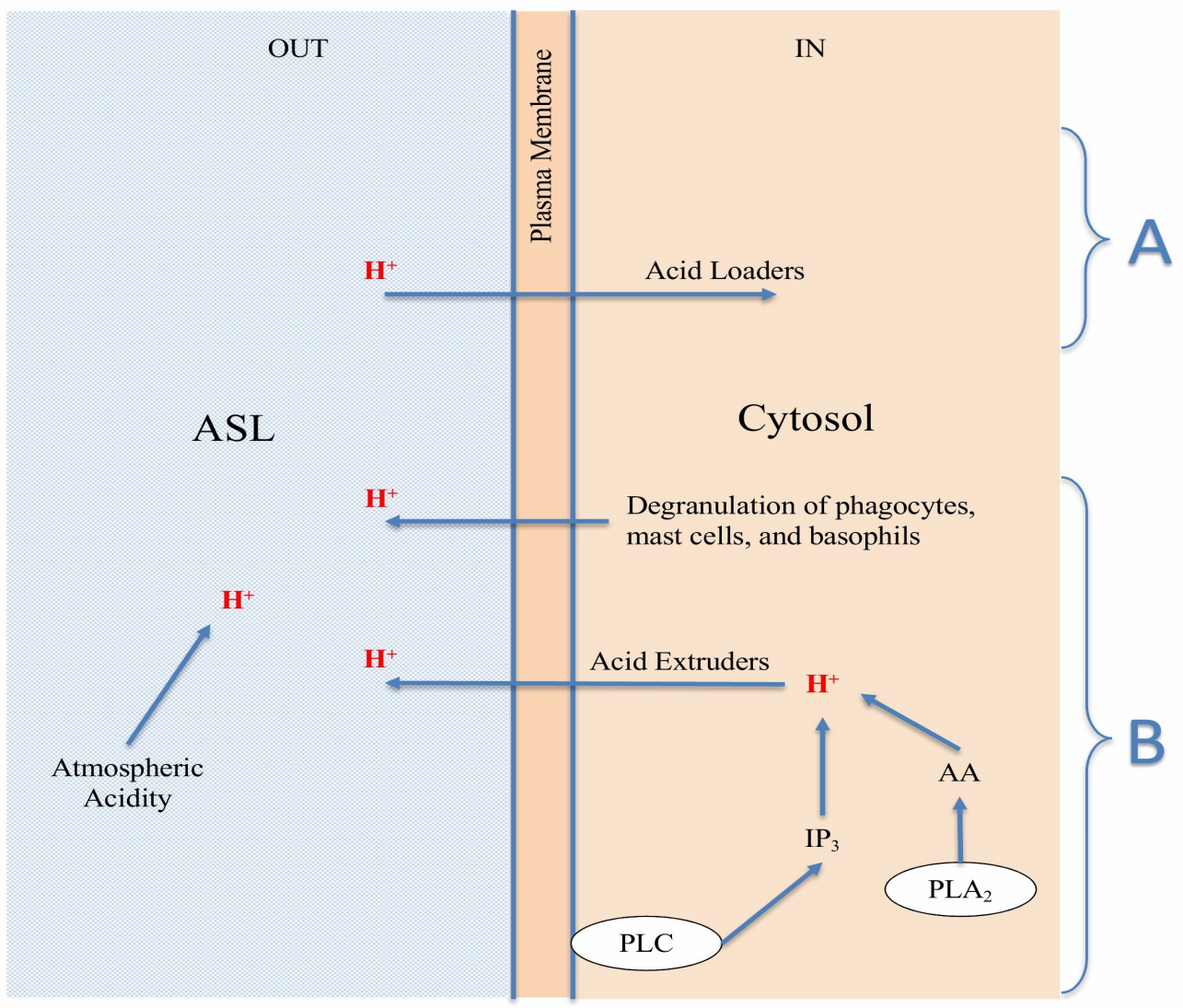

Fig. 2. Biochemical routes for variation in pH of the Airway Surface Liquid (ASL)

A) Acid Loaders: TRP, ORAI, and ASICS channels; CO2/Carbonic Anhydrase system; SLC26

Exchanger; Grotthuss Shuttling; etc.

B) Acid Extruders: Hv1, TRP, and CFTR channels; ATP pumps; NHE and SCL4A7 transporters; Grotthuss Shuttling; etc.

$\mathrm{PLA}_{2}=$ Phospholipase $\mathrm{A}_{2}$

$\mathrm{PLC}=$ Phospholipase C

IP3 = Inositol 1,4,5-trisphosphate

AA $=$ Arachidonic Acid 
There are numerous parallel ways for the surface cells of the respiratory airways to acidify the ASL. In addition to the above-mentioned degranulation, which involves the secretion of granules or acid vesicles, cells can use acid extruders as channels, transporters and pumps to transfer $\mathrm{H}^{+}$ externally ${ }^{121,129-133}$. Also the Cystic fibrosis transmembrane conductance regulator (CFTR) plays an important role in the acidification of the ASL ${ }^{105,134}$. Moreover, the excess protons in the cytosol may exit the cell via Grotthuss shuttling $106,119,120$.

8. In addition to the endogenous acids described above in points 5,6 and 7 , which are transferred by the cells to the ASL by means of extrusion and/or degranulation, the acidification of the ASL may be due to exogenous acids and hence, possibly, to the presence and direct action of atmospheric acid pollutants.

All four processes of acidification described in points 5-8, and in Fig. 2, B, can contribute separately or simultaneously to lowering ASL $\mathrm{pH}$. The pathological consequences of the lowering of ASL pH, caused by either exogenous or endogenous acids, can include increase in mucus viscosity, decrease of ciliary beat frequency, recruitment of pro-inflammatory mediators, oedema, leukocyte infiltration, AHR, tissue remodelling, and damage $20,35,45,133,134$. These consequences

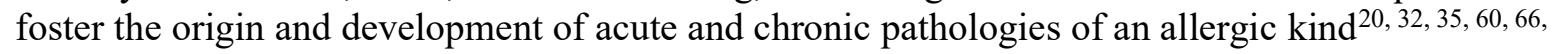
125,134 .

\section{Discussion}

\section{Difficulties to overcome}

It is difficult to demonstrate if a common causal mechanism for the onset and increasing spread of inflammatory allergic and nonallergic diseases exists and how it works, but it is very important. As far in our knowledge, a great number of interesting publications is available in the literature on this theme, but none specifically takes into consideration from a biochemical point of view also the inflammatory nonallergic manifestations. The association of airway inflammation, bronchoconstriction and/or asthma with acids ${ }^{19,20,28-32,35,125}$ and more specifically of allergic responses with some particular acids, such as sulphurous ${ }^{28,30}$, and $\mathrm{AA}^{4,53,136}$, has long been known. The association of environmental acids with allergic sensitization ${ }^{32,137}$ and the hypothesis that these diseases might share a common mechanism ${ }^{14,15,17}$ have been taken into consideration more recently. Some critical issues emerge from reading the existing toxicological studies. Important criticalities arise above all from the features of the proton $\left(\mathrm{H}^{+}\right.$ion) (small, very mobile and fast, able to interact with many molecular entities and to modify the conformation of the proteins, replacing the ions bound to them such as $\mathrm{Ca}^{2+}$ ). These properties, which make it an ideal activation factor, are at the same time an obstacle to detection by normal instruments. In addition, the interdependence of the concentrations of $\mathrm{H}^{+}$and $\mathrm{Ca}^{2+}$ suggests that the latter varies rapidly and in parallel with the former. This depends on the intrinsic chemical properties of the two ions. Even in simple aqueous solutions without biological structures, it can be observed that the addition of acids quickly solubilizes the bound calcium and therefore produces an increase in $\left[\mathrm{Ca}^{2+}\right]$, whilst the addition of alkali causes it to deposit and therefore reduces $\left[\mathrm{Ca}^{2+}\right]$.

Other criticalities arise from the difficulty in isolating a single pollutant and in the case of the PMs their non-specific composition. There are a number of variables in play, some of which are hard to investigate. Studies often include different cells and different experimental conditions in terms of method and duration. It is therefore very difficult to evaluate and compare data and conclusions. This should be carefully considered in experimental studies.

\section{Possible deductions}

This research on the acidification/increase of $\left[\mathrm{H}^{+}\right]$in external cells and epithelia highlights that the acidity of external epithelia can have both exogenous (environmental acidity) and endogenous 
(phospholipase activation) origins (Fig. 2, B) and therefore the cellular calcium homeostasis can be altered from both outside and inside.

By the release of protons in various ways via acid loaders and acid extruders through the plasma membrane, the acids can increase $\left[\mathrm{Ca}^{2+}\right]_{\mathrm{c}}$ and activate immune cells. The parallelism and interdependence of the concentrations of $\mathrm{H}^{+}$and $\mathrm{Ca}^{2+}$ and the well-known ability of $\mathrm{H}^{+}$to easily replace $\mathrm{Ca}^{2+}$ in its binding sites are the basic facts that suggest that the various means of intracellular acidification, of both exogenous and endogenous origin, have a common mechanism, with $\mathrm{H}^{+}$acting as a stimulus for the increase in $\left[\mathrm{Ca}^{2+}\right]_{\mathrm{c}}$.

Many enzymes at the basis of the allergic and non-allergic inflammatory response have catalytic activity, strictly dependent on $\mathrm{H}^{+}$and/or $\mathrm{Ca}^{2+}$ as cofactors. The PLC and PLA $\mathrm{A}_{2}$ themselves are Cadependent. Therefore, intracellular acidification, of both exogenous and endogenous origin may induce acute inflammatory reactions and hypersensitivity through the activation of specific enzymes and the modulation of their action. Furthermore, exogenous and/or endogenous acidification may favour the lowering of the ASL $\mathrm{pH}$ and the reiteration of the acid stimulus, triggering the recruitment of pro-inflammatory mediators and chronic disease. To sum up, it is possible that:

A) Environmental acidity increases the sensitivity of epithelial surfaces and promotes AHR;

B) Exogenous and endogenous acids contribute to both the decrease in ASL pH and the increase of ASM basal tone, thus favouring bronchoconstriction;

C) The excess of temporary intracellular acidification produces acute manifestations of an allergic kind;

D) Recurrent or continuous acidification is the basis of airway inflammation, hyper-responsiveness, tissue remodelling, and chronicity.

Accordingly, the impairment of $\mathrm{H}^{+} / \mathrm{Ca}^{2+}$ homeostasis and particularly their abnormal higher concentrations can foster the onset, continuation, and multimorbidity of illnesses, such as inflammatory allergic and nonallergic acute and chronic diseases. The eight entry/exit pathways for the protons, as described above, are based on physiological activation mechanisms and therefore can be carried out either in healthy or sensitized subjects. The variety of possible paths to increase and control intracellular $\mathrm{H}^{+} / \mathrm{Ca}^{2+}$ and its numerous interactions in the human organism require further studies to explain the diversity of responses and existing situations.

A relation between oxidative or nitrosative stress and acid stress has also been put forward ${ }^{20}$. Notoriously, protons can readily produce modifications in the conformation of proteic molecules. Moreover, environmental pollutants have been associated with some asthma phenotypes through the mediation of IL-13 and DNA methylation ${ }^{2}$. DNA methylation is favoured by heavy metals, which in turn are made available by acid mobilization. Certain metal constituents of $\mathrm{PM}_{2.5}$ were associated with circulating biomarkers of endothelial function ${ }^{138}$. Therefore, environmental acids might play a role in genetic/environmental interactions, by inducing epigenetic modifications with consequent allergic sensitization.

\section{Conflicts and discrepancies}

In contrast to new answers suggested in points A-D, one question arises spontaneously: 'If acids play an important role in asthma and allergies, how are the pathologic responses to basic compounds to be explained?' As recently pointed out ${ }^{77}$, most so-called pseudo-allergic compounds are basic. The answer, given by the same author, is that pseudo-allergic compounds activate $\mathrm{G}$ proteins, directly or through GCPRs ${ }^{77}$. Accordingly, the subsequent steps follow the abovementioned PLC/IP 3 pathway, involving acid generation and thus release of $\mathrm{H}^{+} / \mathrm{Ca}^{2+}$. Some other studies ${ }^{12,139,140}$ have shown that in vivo cellular alkalinization causes a substantial increase of $\left[\mathrm{Ca}^{2+}\right]$ c. This is not in contradiction with what is reported here, in the "Intracellular $\mathrm{H}^{+ \text {" }}$ paragraph, because different events are involved. In their article, Yu et al. ${ }^{112}$ describe studies of the regulatory not activation mechanisms, and some authors think the increase in $\left[\mathrm{Ca}^{2+}\right]_{\mathrm{c}}$ caused by the 
alkalinization may be due to influx ${ }^{139}$ or the inhibition of $\mathrm{Ca}^{2+} \mathrm{ATPase}^{140}$. In the "Intracellular $\mathrm{H}^{+}$" paragraph, we describe the rapid and transient increase in $\left[\mathrm{Ca}^{2+}\right]$, caused by the activation of phospholipase or the entry of extracellular $\mathrm{H}^{+}$, prior to the influx.

\section{Conclusions}

Acid pollutants can have toxic, cumulative effects on human epithelia via the release of protons. Protons can affect cellular homeostasis from both outside and inside. Therefore, it can be assumed that intracellular acidification, and the consequent increase of $\mathrm{Ca}^{2+}$ concentration induced by protons generated either by acid pollutants or endogenous phospholipases, may be at the basis of the shared causal mechanism of acid stress and multimorbidity of pathological, respiratory, and hypersensitivity reactions. Moreover, acid environmental pollutants can contribute to the development and growing spread of inflammatory allergic and nonallergic pathologies worldwide. Further studies are required to clarify: a) the cellular $\mathrm{H}^{+} / \mathrm{Ca}^{2+}$ homeostasis, with particular regard to proton generation and control, the interplays between protons and other signalling molecules, as well as between protons and mitochondria; b) the specificity and the activation pathways of $\mathrm{G}$ proteins in general, and in relation to protons, also considering the very high number of GPCRs discovered in recent years; c) the ability of ion channels to transfer $\mathrm{H}^{+}$into cells, together with an investigation of the permeability of plasma membranes to gaseous pollutants, such as $\mathrm{NO}, \mathrm{NO}_{2}$, $\mathrm{SO}_{2}$, and particularly to $\mathrm{CO}_{2}$, because $\mathrm{CO}_{2}$ may have considerable influence on intracellular $\mathrm{pH}$ as well as on titratable acidity. Studies of acidity are often limited to measuring only $\mathrm{pH}$, but the measurement of both $\mathrm{pH}$ and titratable acidity is indicated for better evaluation purposes.

Identifying and understanding the mechanisms of feedback and control of the different processes of cytosolic acidification, either of internal or external origin, temporary or lasting, and their physiopathological consequences represents a major challenge for future research.

Reducing air acidity may be an important aim to limit the spread of the pathologies taken into consideration in the present study, and to improve health, especially in children and in frail subjects, more exposed to the risk of diseases. We believe our research calls attention to the fundamental importance of $\mathrm{H}^{+} / \mathrm{Ca}^{2+}$ inter-dependence and hope it contributes to further studies into allergic diseases and the identification of the molecular causes of these pathologies.

\section{Declarations}

Consent for publication: All authors agree on the publication.

Funding: This work received no external funding.

Competing Interests: Giuliano Molinari has a patent, Italian Patent N. 0001424963 issued. The authors have no other conflicts of interest to declare.

Authors' Contributions: Giuliano Molinari wrote the first draft manuscript, titled: 'Intracellular acidification, a shared mechanism for the onset, spread, and comorbidity of allergies'. Laura Molinari and Elsa Nervo reorganized and developed the initial draft, with the addition of further acidification pathways, highlighting the role of environmental acids. All the authors reviewed and contributed to the development of the final paper.

Acknowledgements: We would like to express our lasting gratitude to Emeritus Professor Paola Vita Finzi, Department of Chemistry, University of Pavia, Professor Francesca Levi-Schaffer, School of Pharmacy, The Hebrew University of Jerusalem, and Doctor Giselda Colombo, Unit of Immunology, Rheumatology, Allergy, and Rare Diseases, IRCCS Ospedale San Raffaele, Milan for reading the manuscript and for their helpful and valuable suggestions. 


\section{References}

1. Thomsen SF. Epidemiology and natural history of atopic diseases. Eu Clin Respir J. 2015;2(1):24642.

2. Bønnelykke $\mathrm{K}$, Ober C. Leveraging gene-environment interactions and endotypes for asthma gene discovery. J Allergy Clin Immunol. 2016;137:667-79.

3. Bowatte G, Lodge CJ, Knibbs LD, Lowe AJ, Erbas B, Dennekamp M, et al. Traffic-related air pollution exposure is associated with allergic sensitization, asthma, and poor lung function in middle age. J Allergy Clin Immunol. 2017;139:122-129.

4. Bousquet J, Khaltaev N, Cruz AA, Denburg J, Fokkens WJ, et al. Allergic Rhinitis and its Impact on Asthma (ARIA) 2008 Update. Allergy. 2008;63:8-160.

5. D'Amato G, Holgate ST, Pawankar R, Ledford D, Cecchi L, Al-Ahmad M, et al. Meteorological conditions, climate change, new emerging factors, and asthma and related allergic disorders. A statement of the World Allergy Organization. World Allergy Organ J. 2015;8:25.

6. Song W-J, Kang M-G, Chang Y-S, Cho S-H. Epidemiology of adult asthma in Asia: toward a better understanding. Asia Pac Allergy. 2014;4:75-85.

7. WHO Guidelines for indoor air quality, in WHO Housing and Health Guidelines, Geneva: World Health Organization, 2018;90-96. ISBN-13:978-92-4-155037-6.

8. Nicolaou N, Siddique N, Custovic A. Allergic disease in urban and rural populations: Increasing prevalence with increasing urbanization. Allergy. 2005;60:1357-1360.

9. Rojas-Rueda D, Turner MC. Commentary: Diesel, Cars, and Public Health. Epidemiology. 2016;27:159-162.

10. Gehring U, Gruzieva O, Agius RM, Beelen R, Custovic A, Cyrys J, et al. Air Pollution Exposure and Lung Function in Children: The ESCAPE Project. Environ Health Perspect. 2013;121:1357-64.

11. WHO (World Health Organization): WHO Regional Office for Europe. Review of evidence on health aspects of air pollution - REVIHAAP Project Technical Report. 2013. Available from:

http://www.euro.who.int/_data/assets/pdf_file/0004/193108/REVIHAAP-Final-technical-report-finalversion.pdf

12. Kim D, Chen Z, Zhou LF, Huang SX. Air pollutants and early origins of respiratory diseases. Chronic Dis Transl Med. 2018;4(2):75-94. doi:10.1016/j.cdtm.2018.03.003.

13. Bowatte G, Lodge C, Lowe AJ, Erbas B, Perret J, Abramson MJ, et al. The influence of childhood trafficrelated air pollution exposure on asthma, allergy and sensitization: a systematic review and a metaanalysis of birth cohort studies. Allergy. 2015;70:245-256.

14. Bousquet J, Anto JM, Akdis M, Auffry C, Keil T, Momas I, et al. Paving the way of systems biology and precision medicine in allergic diseases: the MeDALL success story. Mechanisms of the Development of Allergy; EU FP7-CP-IP; Project No: 261357;2010-2015. Allergy. 2016;71:1513-1525.

15. Anto JM, Bousquet J, Akdis M, Auffray C, Keil T, Momas I, et al. Mechanisms of the Development of Allergy (MeDALL): Introducing novel concepts in allergy phenotypes. J Allergy Clin Immunol. 2017;139:388-399.

16. Hoyte FCL, Nelson HS. Recent advances in allergic rhinitis. F1000Res. 2018;7:F1000 Faculty Rev-1333. Published 2018 Aug 23. doi:10.12688/f1000research.15367.1

17. Pinart $M$, Benet $M$, Annesi-Maesano I, von Berg A, Berdel D, Carlsen $K C L$, et al. Comorbidity of eczema, rhinitis, and asthma in IgE-sensitised and non-IgE-sensitised children in MeDALL: a population-based cohort study. Lancet Respir Med. 2014;2:131-140.

18. Liu L, Poon R, Chen L, Frescura AM, Montuschi P, Ciabattoni G, et al. Acute Effects of Air Pollution on Pulmonary Function, Airway Inflammation, and Oxidative Stress in Asthmatic Children. Environ Health Perspect. 2009;117:668-674.

19. Balmes JR, Fine JM, Gordon T, Sheppard D. Potential Bronchoconstrictor Stimuli in Acid Fog. Environ Health Perspect. 1989;79:163-6.

20. Ricciardolo FL, Gaston B, Hunt J. Acid stress in the pathology of asthma. J Allergy Clin Immunol. 2004;113:610-619.

21. Héroux ME, Anderson HR, Atkinson R, Brunekreef B, Cohen A, Forastiere F, et al. Quantifying the health impacts of ambient air pollutants: recommendations of a WHO/Europe project. Int J Public Health. 2015;60:619-627.

22. Zhang Y, Wang SG, Ma YX, Shang KZ, Cheng YF, Li X, et al. Association between Ambient Air Pollution and Hospital Emergency Admissions for Respiratory and Cardiovascular Diseases in Beijing: a Time Series Study. Biomed Environ Sci. 2015;28:352-363. 
23. Paulin L, Hansel N. Particulate air pollution and impaired lung function. F1000Res. 2016, Feb 22;5. pii: F1000 Faculty Rev-201.

24. Endeward V, Al-Samir S, Itel F, Gros G. How does carbon dioxide permeate cell membranes? A discussion of concepts, results and methods. Front Physiol. 2014;4:382.

25. Koehler C, Paulus M, Ginzkey C, Hackenberg S, Scherzad A, Ickrath P, et al. The Proinflammatory Potential of Nitrogen Dioxide and Its Influence on the House Dust Mite Allergen Der p 1. Int Arch Allergy Immunol. 2016;171:27-35.

26. Reno AL, Brooks EG, Ameredes BT. Mechanisms of Heightened Airway Sensitivity and Responses to Inhaled $\mathrm{SO}_{2}$ in Asthmatics. Environ Health Insights. 2015;9:13-25.

27. Yorifuji T, Suzuki E, Kashima S. Hourly differences in air pollution and risk of respiratory disease in the elderly: a time-stratified case-crossover study. Environ Health. 2014;13:67.

28. Vally H, Misso NLA. Adverse reactions to the sulphite additives. Gastroenterol Hepatol Bed Bench. 2012;5:16-23.

29. Schlesinger RB, Chen LC, Finkelsein I, Zelikoff JT. Comparative potency of inhaled acidic sulphates: speciation and the role of hydrogen ion. Environ Res. 1990;52:210-24.

30. Fine JM, Gordon T, Sheppard D. The Roles of $\mathrm{pH}$ and Ionic Species in Sulfur Dioxide- and Sulfite-Induced Bronchoconstriction. Am Rev Respir Dis. 1987;136:1122-1126.

31. Mirić M, Plavec D. Risk of Acute Bronchospasm and Bronchial Hyperreactivity from Inhaled Acid Aerosol in 79 Healthy Subjects: Randomized, Double-blind Controlled Trial. Croat Med J. 2004;45:709-14.

32. Kamide Y, Ishizuka T, Tobo M, Tsurumaki H, Aoki H, Mogi C, et al. Acidic environment augments FceRImediated production of IL-6 and IL-13 in mast cells. Biochem Biophys Res Commun. 2015;464:949-55.

33. Trevani AS, Andonegui G, Giordano M, et al. Extracellular Acidification Induces Human Neutrophil Activation. J Immunol. 1999;162:4849-4857.

34. Herrmann GM, Kantarci A, Long H, Bernardo J, Hasturk H, Wray LV jr, et al. Simultaneous measurements of cytoplasmic $\mathrm{Ca}^{2+}$ responses and intracellular $\mathrm{pH}$ in neutrophils of localized aggressive periodontitis (LAP) patients. J Leukoc Biol. 2005;78(3):612-619.

35. Martínez D, Vermeulen M, Trevani A, et al. Extracellular Acidosis Induces Neutrophil Activation by a Mechanism Dependent on Activation of Phosphatidylinositol 3-Kinase/Akt and ERK Pathways. J Immunol. 2006;176:1163-1171.

36. Vermeulen M, Giordano M, Trevani AS, et al. Acidosis improves uptake of antigens and MHC class Irestricted presentation by dendritic cells. J Immunol. 2004;172:3196-3204.

37. Kottyan LC, Collier AR, Cao KH, Niese KA, Hedgebeth M, Radu CG, et al. Eosinophil viability is increased by acidic pH in a cAMP- and GPR65-dependent manner. Blood. 2009;114:2774-2782.

38. Smith-Garvin JE, Koretzky GA, Jordan MS. T Cell Activation. Annu Rev Immunol. 2009; 27:591-619.

39. Wang X, Hatatani K, Sun Y, Fukamachi T, Saito H, Kobayashi H. TCR Signaling via ZAP-70 Induced by CD 3 Stimulation is More Active Under Acidic Conditions. J Cell Sci Ther. 2012;S:15.

40. Huber V, Camisaschi C, Berzi A, Ferro S, Lugini L, Triulzi T, et al. Cancer acidity: An ultimate frontier of tumor immune escape and a novel target of immunomodulation. Seminars in Cancer Biology. 2017;(43):7489.

41. Narita A, Yawata K, Nagata M, et al. Effects of Extracellular Acidification on Intracellular pH and ATPInduced Calcium Mobilization in Rabbit Lens Epithelial Cells. Yonago Acta Med. 1999;42:51-59.

42. Chin WC, Quesada I, Nguyen T, Verdugo P. Oscillations of pH inside the secretory granule control the gain of $\mathrm{Ca}^{2+}$ release for signal transduction in goblet cell exocytosis. Novartis Found Symp. 2002;248:13241; discussion 141-9,277-82.

43. Ichimonji I, Tomura H, Mogi C, Sato K, Aoki H, Hisada T, et al. Extracellular acidification stimulates IL-6 production and $\mathrm{Ca}^{2+}$ mobilization through proton-sensing OGR1 receptors in human airway smooth muscle cells. Am J Physiol Lung Cell Mol Physiol. 2010;299:L567-L577.

44. Saxena H, Deshpande DA, Tiegs BC, Yan H, Battafarano RJ, Burrows WM, et al. The GPCR OGR1 (GPR68) mediates diverse signalling and contraction of airway smooth muscle in response to small reductions in extracellular pH. Br J Pharmacol. 2012;166(3):981-90.

45. Prakash YS. Airway smooth muscle in airway reactivity and remodeling: what have we learned? Am J Physiol Lung Cell Mol Physiol. 2013;305:L912-L933.

46. Kim D, Liao J, Hanrahan JW. The buffer capacity of airway epithelial secretions. Front Physiol. 2014;5:188.

47. Wilton DC, Waite M. Phospholipases, in: D.E. Vance and J.E. Vance (Eds.) Biochemistry of lipids, Lipoproteins and Membranes (5th Edn.), 2008;(11):305-329.

48. Hu YL, Mi X, Huang C, Wang HF, Song JR, Shu Q, et al. Multiple $\mathrm{H}^{+}$sensors mediate the extracellular acidification-induced $\left[\mathrm{Ca}^{2+}\right]$ i elevation in cultured rat ventricular cardiomyocytes. Sci Rep. 2017;7:44951. 
49. Huang J, Liu CH, Hughes SA, Postma M, Schwiening CJ, Hardie RC. Activation of TRP channels by protons and phosphoinositide depletion in Drosophila photoreceptors. Curr Biol. 2010;20:189-197.

50. Smith JB, Dwyer SD, Smith L. Lowering Extracellular pH Evokes Inositol Polyphosphate Formation and Calcium Mobilization. J Biol Chem. 1989;264:8723-8728.

51. Tsunoda Y, Matsuno K, Tashiro Y. Cytosolic acidification leads to $\mathrm{Ca}^{2+}$ mobilization from intracellular stores in single and populational parietal cells and platelets. Exp Cell Res. 1991;193(2):356-63.

52. Donoso P, Beltrán M, Hidalgo C. Luminal pH regulated calcium release kinetics in sarcoplasmic reticulum vesicles. Biochemistry. 1996;35(41):13419-25.

53. Chen WH, Chen CR, Yang KT, Chang WL, Su MJ, Wu CC, et al. Arachidonic acid-induced $\mathrm{H}+$ and $\mathrm{Ca}^{2+}$ increases in both the cytoplasm and nucleoplasm of rat cerebellar granule cells. J Physiol. 2001;537(Pt 2):497510.

54. Bates RC, Fees CP, Holland WL, Winger CC, Batbayar K, Ancar R, et al. Activation of Src and release of intracellular calcium by phosphatidic acid during Xenopus laevis fertilization. Dev Biol. 2014;386(1):165-180.

55. Busa WB, Nuccitelli R. Metabolic regulation via intracellular pH. Am J Physiol. 1984;246:R409-R438.S.

56. Iida S, Potter JD. Calcium binding to calmodulin. Cooperativity of the calcium-binding sites, J Biochem. 1986;99:1765-1772.C.

57. Berridge MJ, Bootman MD, Roderick HL. Calcium signalling: dynamics, homeostasis and remodelling. Nat Rev Mol Cell Biol. 2003;4:517-29.

58. Lee RJ, Foskett JK. Ca ${ }^{2+}$ signaling and fluid secretion by secretory cells of the airway epithelium. Cell Calcium. 2014;55:325-336.

59. Ma HT, Beaven MA. Regulators of $\mathrm{Ca}^{2+}$ signaling in mast cells: potential targets for treatment of mast-cell related diseases? In Gilfillan AM, Metcalfe DD editors. Mast Cell Biology: Contemporary and emerging topics. Landes Bioscience and Springer Science+Business Media, 2011; chapter 5, 62-90.

60. Chapman DG, Irvin CG. Mechanisms of airway hyper-responsiveness in asthma: the past, present and yet to come. Clin Exp Allergy. 2015;45:706-719.

61. Ozier A, Allard B, Bara I, et al. The Pivotal Role of Airway Smooth Muscle in Asthma Pathophysiology. J Allergy (Cairo). 2011;2011:742710.

62. Galli SJ, Tsai M. IgE and mast cells in allergic disease. Nat Med. 2012; 18(5): 693-704.

63. Vines CM, Prossnitz ER. Mechanisms of G protein-coupled receptor-mediated degranulation. FEMS Microbiology Letters. 2004;236:1-6.

64. Maurer M, Pucillo C. What we know (and don't know) about the biology and functions of mast cells and basophils. Special Issue. Immunol Rev. 2018;282(1):5-7.

65. Miyake K, Karasuyama H. Emerging roles of basophils in allergic inflammation. Allergol Int. 2017;66(3):382391.

66. Olivera A, Beaven MA, Metcalfe DD. Mast cells signal their importance in health and disease. J All Clin Immunol. 2018;142(2):381-393.

67. Gilfillan AM, Peavy RD, Metcalfe DD. Amplification mechanisms for the enhancement of antigen mediated mast cell activation. Immunol Res. 2009 ;43(1-3):15-24.

68. Suzuki R. The Emerging Picture of Mast Cell Activation: The Complex Regulatory Network of High-Affinity Receptor for Immunoglobulin E Signaling. Biol Pharm Bull. 2017;40(11):1828-1832.

69. Kuehn HS, Gilfillan AM. G Protein-coupled receptors and the modification of FceRI-mediated mast cell activation. Immunol Lett. 2007;113(2):59-69.

70. Subramanian H, Gupta K, Ali H. Roles of MAS-related G protein coupled receptor-X2 (MRGPRX2) on mast cell-mediated host defense, pseudoallergic drug reactions and chronic inflammatory diseases. J Allergy Clin Immunol. 2016;138(3):700-710.

71. Gaudenzio N, ..., Espinosa E, Galli SJ. Different activation signals induce distinct mast cell degranulation strategies. J Clin Invest. 2016;126(10):3981-3998.

72. Gao Z-G, Jacobson KA. Purinergic Signaling in Mast Cell Degranulation and Asthma. Front Pharmacol. 2017;8:947.

73. Jairaman A, Maguire CH, Schleimer RP, Prakriya M. Allergens stimulate store-operated calcium entry and cytokine production in airway epithelial cells. Sci Rep. 2016;6:32311.

74. Nakano M, Ito K, Y uno T, Soma N, Aburakawa S, Kasai K, et al. UDP/P2Y6 receptor signaling regulates IgEdependent degranulation in human basophils. Allergol Int. 2017;66:574-580.

75. Aoki H, Mogi C, Okajima F. Ionotropic and Metabotropic Proton-Sensing Receptors Involved in Airway Inflammation in Allergic Asthma. Mediators Inflamm. 2014:712962.

76. Alexander SPH, et al. The concise guide to pharmacology 2017/18: G protein-coupled receptors. Br J Pharmacol. 2017;174:S17-S129. 
77. Seifert R. How do basic secretagogues activate mast cells? Naunyn-Schmiedeberg's Arch Pharmacol. 2015;388:279-281.

78. Chen Y-C, et al. Differential $\mathrm{Ca}^{2+}$ mobilization and mast cell degranulation by FceRI- and GPCR-mediated signaling. Cell Calcium. 2017;67:31-39.

79. Gilfillan AM, Tkaczyk C. Integrated signalling pathways for mast-cell activation. Nat Rev Immunol. 2006;6(3):218-30.

80. Gilfillan AM, Peavy RD, Metcalfe DD. Amplification mechanisms for the enhancement of antigen mediated mast cell activation. Immunol Res. 2009;43(1-3):15-24.

81. Cocco L, Follo MY, Manzoli L, Suh P-G. Phosphoinositide-specific phospholipase C in health and disease. J Lip Res. 2015;53:1853-1860.

82. Nakamura Y, Fukami K. Regulation and physiological functions of mammalian phospholipase C. J Biochem. 2017;161(4):315-321.

83. Molinari G. Is hydrogen ion $(\mathrm{H}(+))$ the real second messenger in calcium signalling? Cell Signal. 2015;27:1392-7.

84. Berridge MJ: The inositol trisphosphate/calcium signaling pathway in health and disease. Physiol Rev. 2016;96:1261-1296.

85. Fujishima H, Sanchez Mejia RO, Bingham CO, Lam BK, Sapirstein A, Bonventre JV, et al. Cytosolic phospholipase $\mathrm{A}_{2}$ is essential for both the immediate and the delayed phases of eicosanoid generation in mouse bone marrow-derived mast cells. Proc Natl Acad Sci USA. 1999;96:4803-4807.

86. Leslie CC. Cytosolic phospholipase $\mathrm{A}_{2}$ : Physiological function and role in disease. J Lipid Res. 2015;56(8):1386-402.

87. Damron DS, Van Wagoner DR, Moravec CS, Bond M. Arachidonic acid and endothelin potentiate $\mathrm{Ca}^{2+}$ transients in rat cardiac myocytes via inhibition of distinct $\mathrm{K}^{+}$channels. J Biol Chem. 1993;268(36):27335-44.

88. Dennis EA, Norris PC. Eicosanoid Storm in Infection and Inflammation. Nat Rev Immunol. 2015;15(8):511523.

89. Hanna VS, Hafez EAA. Synopsis of arachidonic acid metabolism: A review. J Adv Res. 2018;11:23-32.

90. Ma HT, Beaven MA. Regulators of $\mathrm{Ca}(2+)$ signaling in mast cells: potential targets for treatment of mast cellrelated diseases? Adv Exp Med Biol. 2011;716:62-90.

91. Parenti A, De Logu F, Geppetti P, Benemei S. What is the evidence for the role of TRP channels in inflammatory and immune cells? British J pharmacol. 2016;(173):953-969.

92. Ambudkar IS, Brito de Souza L, Ong HL. TRPC1, Orai1, and STIM1 in SOCE: Friends in tight spaces. Cell Calcium. 2017;63:33-39.

93. Fahrner M, Stadlbauer M, Muik M, Rathner P. Stathopulos P, Ikura M, et al. A dual mechanism promotes switching of the Stormorken STIM1 R304W mutant into the activated state. Nat Commun. 2018;9(1):825.

94. Nicaise G, Maggio K, Thirion S, Horoyan M, Keicher E. The calcium loading of secretory granules. A possible key event in stimulus-secretion coupling. Biol Cell. 1992;75(2):89-99.

95. Wernersson S, Pjler G. Mast cell secretory granules: armed for battle. Nat Rev Immunol. 2014;14:478-494.

96. Murakami M, Yamamoto K, Miki Y, Murase R, Sato H, Taketomi Y. The Roles of the Secreted Phospholipase $\mathrm{A}_{2}$ Gene Family in Immunology. Adv Immunol. 2016;132:91-134.

97. Pejler G, Hu Frisk JM, Sjöström D, Paivandy A, Öhrvik H. Acidic pH is essential for maintaining mast cell secretory granule homeostasis. Cell Death Dis. 2017;8(5)22785.

98. Galli SJ, Tsai M, Marichal T, Tchougounova E, Reber LL, Pejler G. Approaches for Analyzing the Roles of Mast Cells and Their Proteases In Vivo. Adv Immunol. 2015;126:45-127.

99. Kormelink TG, Arkesteijn GJA, van de Lest CHA, Geerts WJC, Goerdayal SS, et al. Mast Cell Degranulation Is Accompanied by the Release of a Selective Subset of Extracellular Vesicles That Contain Mast CellSpecific Proteases. J Immunol. 2016;197:3382-3392.

100. Chapman DG, Irvin CG. Mechanisms of airway hyper-responsiveness in asthma: the past, present and yet to come. Clin Exp Allergy. 2015;45:706-719.

101. Swietach P, Youm JB, Saegusa N, Leem CH, Spitzer KW, Vaughan-Jones RD. Coupled $\mathrm{Ca}^{2+} / \mathrm{H}^{+}$transport by cytoplasmic buffers regulates local $\mathrm{Ca}^{2+}$ and $\mathrm{H}^{+}$ion signaling. Proc Natl Acad Sci USA. 2013;110(22):E206473.

102.ZhangX, Gueguinou M, Trebak M. Store-Independent Orai Channels Regulated by STIM, in Calcium Entry Channels in Non-Excitable Cells, Kozak JA and Putney JW jr Editors, Methods in signal transduction series. CRC Press, Taylor \& Francis Group, 2018;11:197-213.

103.Lee SE, Lee SH. Skin Barrier and Calcium. Ann Dermatol. 2018;30(3):265-275.

104. Brune K, Frank J, Schwingshackl A, Finigan J, Venkataramana KS. Pulmonary epithelial barrier function: some new players and mechanisms. Am J Physiol Lung Cell Mol Physiol. 2015;308: L731-L745. 
105. De Rose V, Molloy K, Gohy S, Pilette C, Greene CM. Airway Epithelium Dysfunction in Cystic Fibrosis and COPD. Mediators Inflamm. 2018;8:1309746.

106. Decoursey TE. Voltage-Gated Proton Channels and Other Proton Transfer Pathways. Physiol Rev. 2003;83:475-579.

107.Hellwig N, Plant TD, Janson W, Schäfer M, Schultz, G, Schaefer M. TRPV1 acts as proton channel to induce acidification in nociceptive neurons. J Biol Chem. 2004;279:34553-34561.

108. Jiang J, Li M, Yue L. Potentiation of TRPM7 inward currents by protons. J Gen Physiol. 2005;126:137-150.

109. Numata T, Okada Y. Proton conductivity through the human TRPM7 channel and its molecular determinants. J Biol Chem. 2008;283:15097-15103.

110. Starkus JG, Fleig A, Penner R. The calcium-permeable non-selective cation channel TRPM2 is modulated by cellular acidification. J Physiol. 2010;588.8:1227-1240.

111. White JPM, Cibelli M, Urban L, Nilius B, McGeown JG, Nagy I. TRPV4: Molecular Conductor of a Diverse Orchestra. Physiol Rev. 2016;96:911-973.

112. Yu AS, Yue Z, Feng J, Yue L. Regulation of Orai/STIM Channels by pH, in Calcium Entry Channels in NonExcitable Cells, Kozak JA and Putney JW jr Editors, Methods in signal transduction series. CRC Press, Taylor \& Francis Group, 2018;9:161-176.

113. Ramirez GA, Coletto LA, Sciorati C, Bozzolo EP, Manunta P, Rovere-Querini P, et al. Ion Channels and Transporters in Inflammation: Special Focus on TRP Channels and TRPC6. Cells. 2018;7(7):70.

114. Boscardin E, Alijevic O, Hummler E, Frateschi S, Kellenberger S. The function and regulation of acidsensingion channels (ASICs) and the epithelial $\mathrm{Na}^{+}$channel (ENaC): IUPHAR Review 19. Brit J Pharmacol. 2016;173:2671-2701.

115.Hulikova A, Vaughan-Jones RD, Niederer SA, Swietach P. CrossTalk opposing view: Physiological $\mathrm{CO}_{2}$ exchange does not normally depend on membrane channels. J Physiol. 2015;593:5029-32.

116. Alka K, Casey JR. Bicarbonate Transport in Health and Disease. IUBMB. 2014;66(9):596-615.

117.Liu X, Li T, Tuo B. Physiological and Pathophysiological Relevance of the Anion Transporter Slc26a9 in Multiple Organs. Front Physiol. 2018;9:1197.

118. Azroyan A, Laghmani K, Crambert G, Mordasini D, Doucet A, Edwards A. Regulation of pendrin by $\mathrm{pH}$ : dependence on glycosylation. Biochem J. 2011;434(1):61-72.

119. Nagle JF, Morowitz HJ. Biophysics Molecular mechanisms for proton transport in membranes. Proc Natl Acad Sci USA. 1978;75(1):298-302.

120.Peng Y, Swanson JMJ, Kang S-g, Zhou R, Voth GA. Hydrated Excess Protons Can Create Their Own Water Wires. J Phys Chem B. 2015;119:9212-9218.

121. Fischer H, Widdicombe JH. Mechanisms of Acid and Base Secretion by the Airway Epithelium. J Membr Biol. 2006;211:139-150.

122. Jayaraman S, ..., Shankar L, Verkman AS. Noninvasive in vivo fluorescence measurement of airway-surface liquid depth, salt concentration, and pH. J Clin Invest. 2001;107(3):317-324.

123. McCreanor J, Cullinan P, Nieuwenhuijsen MJ, Stewart-Evans J, Malliarou E, Jarup L, et al. Respiratory Effects of Exposure to Diesel Traffic in Persons with Asthma. N Engl J Med. 2007;357:2348-58.

124. Brant TC, Yoshida CT, Carvalho TS, Nicola ML, Martins JA, Braga LM, et al. Mucociliary clearance, airway inflammation and nasal symptoms in urban motorcyclists. Clinics. 2014;69:867-870.

125.Hunt JF, Fang K, Malik R, Snyder A, Malhotra N, Platts-Mills TAE, Gaston B. Endogenous Airway Acidification Implications for Asthma Pathophysiology. Am J Respir Crit Care Med. 2000;161:694-699.

126. Brunetti L, Francavilla R, Tesse R, Strippoli A, Polimeno L, LoforeseA, et al. Exhaled breath condensate $\mathrm{pH}$ measurement in children with asthma, allergic rhinitis and atopic dermatitis. Pediatr Allergy Immunol. 2006;17:422-7.

127. Stone KD, Prussin C, Metcalfe DD. IgE, Mast Cells, Basophils, and Eosinophils. J Allergy Clin Immunol. 2010;125:S73-S80.

128. Granata F, Nardicchi V, Loffredo S, Frattini A, Staiano RI, Agostini C, Triggiani M. Secreted phospholipases $\mathrm{A}_{2}$ : A proinflammatory connection between macrophages and mast cells in the human lung. Immunobiol. 2009;214:811-821.

129. Bartoszewski R, Matalon S, Collawn JF. Ion channels of the lung and their role in disease pathogenesis. Am J Physiol Lung Cell Mol Physiol. 2017;313:L859-L872.

130. Seifter JL, Chang H-Y. Extracellular Acid-Base Balance and IonTransport Between Body Fluid Compartments. Physiol. 2017;32:367-379.

131. DeCoursey TE. Voltage and $\mathrm{pH}$ sensing by the voltage-gated proton channel, HV1. J R Soc Interface. 2018;15(141):20180108. 
132. Sedlyarov V, Eichner R, Girardi E, Essletzbichler P, Goldmann U, Nunes-Hasler P, et al. The Bicarbonate Transporter SLC4A7 Plays a Key Role in Macrophage Phagosome Acidification. Cell Host Microbe. 2018;23(6):766-774.e5.

133. Hollenhorst MI, Richter K, Fronius M. Ion Transport by Pulmonary Epithelia. J Biomed Biotechnol. 2011; article ID 174306;16 pages.

134.Lennox AT, Coburn SL, Leech JA, Heidrich EM, Kleyman TR, Wenzel SE, et al. ATP12A promotes mucus dysfunction during Type 2 airway inflammation. Sci Rep. 2018;8(1):2109.

135. Walker MP, Sesma J, Wu B, Stuhlmiller T, Scott D. The characterization of SPX-101, a new peptide promoter of $\mathrm{ENaC}$ internalization, revealed basic mechanistic understanding of EnaC internalization and downstream signaling events. FASEB J. 2017;31:1, supplement1007.32-1007.32.

136.Liu M, Yokomizo T. The role of leukotrienes in allergic diseases. Allergol Int. 2015;64:17-26.

137. Gold MJ, Hiebert PR, Park HY, Stefanowicz D, Le A, Starkey MR, et al. Mucosal production of uric acid by airway epithelial cells contributes to particulate matter-induced allergic sensitization. Mucosal Immunol. 2016;9:809-820.

138. Wu S, Yang D, Pan L, Shan J, Li H, Wei H, et al. Chemical constituents and sources of ambient particulate air pollution and biomarkers of endothelial function in a panel of healthy adults in Beijing, China. Sci Total Environ. 2016;560-561:141-9.

139. Lindeman KS, Croxton TL, Lande B, Hirshman CA. Hypocapnia-induced contraction of porcine airway smooth muscle. Eur Respir J. 1998;12:1046-1052.

140.Li S, Hao B, Lu Y, Yu P, Lee H-C, et al. Intracellular Alkalinization Induces Cytosolic $\mathrm{Ca}^{2+}$ Increases by Inhibiting Sarco/Endoplasmic Reticulum $\mathrm{Ca}^{2+}$-ATPase (SERCA). PloS One. 2012:7(2):e31905. 